\title{
On the frequent deficiency of the ungueal phalanx in the hallux of the Orang Outang
}

\section{E.W.B.}

To cite this article: E.W.B. (1835) On the frequent deficiency of the ungueal phalanx in the hallux of the Orang Outang, Philosophical Magazine Series 3, 7:37, 72-74, DOI: $10.1080 / 14786443508648661$

To link to this article: http://dx.doi.org/10.1080/14786443508648661

$$
\text { 曲 Published online: } 01 \text { Jun } 2009 .
$$

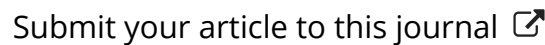

Џ Article views: 2

Q View related articles $\asymp$ 
and valuable papers may be rejected at the last, through confusion and press of business.

"It is also very desirable that the gentlemen who propose to attend should signify their intention early, to the nearest local Treasurer, or to one of the Secretaries for Dublin.

"Information for members, on their arrival, will be given at the Examination Hall of Trinity College, at which place there will be an attendance of proper persons for that purpose during the week of the Meeting and the preceding week.

" The following persons are entitled to be Members of the Association on paying the annual subscription of $1 l$. , or $5 l$., which is the composition in lieu of annual payments.

“). Fellows and members of chartered societies in the British Empire, publishing Transactions. 2. Office-bearers, and members of the councils or managing committees of Philosophical Institutions. 3. Members of any Philosophical Institution recommended by its council or managing committee.

"Other members are also elected by the general committee of the Association, or in the interval of the Meetings by the Council."

\section{ON The FReQuent Deficiency of the ungueal phalanx IN THE HALLUX OF THE ORANG OUTANG.}

In the first portion of the Memoir of the late Sir T. Stamford Raftes, the publication of which was commenced, some years since, in the Zoological Journal, an intention is expressed (Zool. Journ., vol. iii. p. 41 note, ) of noticing, in the sequel, the history of the animal or animals to which the names of Orang Outang and Pongo had been applied by naturalists. In pursuance of this intention (which I designed to fulfill when reciting the contributions to Zoological science of that lamented statesman and philosopher, who had himself called attention to the subject by a remark in his Catalogue of a Zoological collection formed in Sumatra), J examined some of the relations of naturalists and travellers respecting the Orang Outang and its affinities, collected references to others, and entered, to a certain extent, into the discussion of the results derivable from them. The Memoir itself, however, having been afterwards discontinued, the materials thus prepared, like the sketch of the history of the Papuans, (but which I have since inserted in Lond. and Edinb. Phil. Mag., vol. i. p. 466,) and notices of other subjects also connected with the natural history of the Indian Archipelago, have remained unpublished in my possession.

My attention has been recalled to this subject, after the lapse of nearly seven years, by Mr. Owen's recent investigation of the comparative osteology of the Orang Outang and Chimpanzee, towards the further prosecution of which, in relation particularly to certain points in the natural history of the former species of Simia, I have had the pleasure of supplying Mr. Owen with some references.

In the abstract of Mr. Owen's paper given in our last Number (and in the Proceedings of the Zoological Society, No. xxvii.), it is remarked that " The peculiarity of the structure of the hallux first 
noticed by Camper, in seven out of eight Orangs observed by him, viz. its possessing no ungueal phalanx, and consequently no nail, loses much of its importance as a specific character from the fact that the individual dissected at the Society's Museum a few years since had very perfect, but small, black nails, and two phalanges, and that the same number of phalanges exist in the natural skeleton of Lord Amherst's Orang in the Museum of the College of Surgeons." (Lond. and Edinb. Phil. Mag. vol. vi. p. 466-467).

During my search for the references which Mr.Owen had requested, I found that, from a comparison of the various statements then extant respecting the absence or presence of the nail of the hallux in specimens of the $\mathrm{Orang}, \mathrm{I}$ had arrived, in 1828, at the conclusion, that its deficiency was not connected with any distinction of species among the more anthropoid Simice. As this particular subject has again been brought under the attention of zoologists by Mr. Owen's inquiries, it seems proper now to make public, as follows, the remarks upon it which J originally drew up, exactly as they were prepared for insertion in the Memoir of Sir Stamford Raffles. They were intended, I may add, to form a note, to be attached to a synopsis of the additions to Zoology contained in Sir Stamford's "Descriptive Catalogue of a Zoological Collection made in the Island of Sumatra and its vicinity," which was published, in 1821 , in the Transactions of the Linnean Society.

"Sir Stamford states, when describing the Sumatran Simice, [in the Catalogue just referred to, Trans. Linn. Soc., vol. xiii. p. 24],] that in a living specimen of the Orang Outang, Simia Satyrus, Linn., sent from Borneo to the Menagerie at Calcutta in 1819, the nail of the thumb was wanting on the 'hind-feet.' The present imperfect and confused state of the information possessed by naturalists respecting the animal or animals to which the names of Orang Outang and Pongo have been applied, renders it interesting to note this circumstance, since the specimen sent to Calcutta has, no doubt, been preserved for future examination. Camper and Linnæus, it will be remembered, regarded this deficiency of the thumb-nails in the hinder hands as a general character of the Orang Outangs, the truth of which statement, however, has been devied by Cuvier, (Règne Animal, tome i. [edit. 1817] p. 103 [edit. 1829, p. 88])."

"In an article on the Orang Outang of Borneo, by Mr.J. Grant, just published [July, 1828] in No. xvii. of the Edinburgh Journal of Science, we are informed that the great toes (hinder thumbs) of the Sumatran animal so called, described by the late Dr. Abel, have well-defined nails, resembling in shape and size those on the other 'toes' (hinder fingers). In the Pongo or Orang Outang of Borneo described by $W$ urmb, as appears from the same article, ' the nails of the great toes' were much smaller and shorter than the rest. In the hinder hands of an Orang Outang, brought from Borneo a few years since, which are deposited in the collection of the TrinityHouse, Huil, and have lately been described by Dr. Harwood, ' the thumbs are each destitute of a nail, but they have a hardened pro. tuberance in its place.' (See Trans. Linn. Soc., vol. xv. p. 472).

Third Series. Vol. 7. No.37. July 1835. 
Finally, the Bornean animal described by Mr. Grant, in the article just quoted, possesses nails on the hinder thumbs; while Mr. Montgomerie, who had obtained this specimen from Borneo, states that it is the only one he has observed to be possessed of the nail on the great toe; but ' that this is the only particular in which he differs in the slightest degree' from the other Bornean Orang Outangs which he has seen, amounting in number, as appears in the sequel, to at least ten or twelve.

"Whether two or more species of Simin have been confounded together under the appellations of Orang Outang and Pongo, or whether the discrepancies in the accounts of naturalists have arisen from the examination of individuals of different ages, it would be premature to attempt to decide. But the legitimate inference from the facts 'above stated appears to be, that at all events the want of the hinder thumb-nails is a deficiency of fiequent occurrence in the animal or animals in question, unconnected with any important variations in external character or in organization, and unconnected, therefore, with specific distinctions."

I shall not again enter upon the consideration of the subject, further than to observe, that the cursory review which $I$ have thus been led to take of it, at the present time, induces me to modify the opinion which I formerly entertained, as expressed in the concluding paragraph of the above note. Since it appears by uniting the statements of Camper, (Phil.Trans. vol.lxix. p. 145, 146,) Mr. Owen, and Dr.Jeffries, (Phil. Mag., vol. Ixvii. p. 182,) with those which I had originally examined, that out of 26 or 28 individuals of the animal in question, 18 or 20 were deficient in the nail of the hallux, there seems reason to regard it as a distinetion of some importance, though still not amounting to a specific character. With reference also to Mr. Owen's idea that certain characters are indieative of varieties of the Orang inhabiting distinct localities, I may remark that it would seem from the various statements which have been cited, that all the individuals so characterized have been obtained from Borneo, although that island has also furnished a few others exhibiting the normal structure; among 23 or 25 individuals from that locality 18 or 20 not possessing the nail of the kallux. If anything further can be deduced from the facts now before us, it is the probability that there exist in Borneo two varieties of the Orang Outang, one of them having the normal, and the other the said abnormal structure of the hallux. Should this prove to be the fact, it will remain to be determined whether the former Bornean variety is not identical with the Sumatran; and whether the varieties thus characterized are also distinguished by any peculiarities of the cranium, such as those which have been detected by Mr. Owen on comparing two different skulls of the Pongo, or adult Orang Outang of Borneo.

London Institution, June 23, 1835.

E.W. B.

ON OIL OF CINNAMON, \&c,

MM. Dumas and Peligot observe that there occur in commerce several varieties of cinnamon and two of the oil, which are easily 